УДК 811.111: 656.61.

DOI 10.31494/2412-9208-2021-1-1-346-353

\title{
МОРСЬКА АНГЛІЙСЬКА МОВА В ЗАБЕЗПЕЧЕННІ БЕЗПЕКИ МОРЕПЛАВСТВА
}

\section{Olena TISHCHENKO,} Senior Lecturer

\section{MARITIME ENGLISH FOR ENSURING SAFETY OF NAVIGATION Олена ТІЩЕНКО,} старший викладач

\author{
helen020882@gmail.com \\ https://orcid.org/0000-0002-1716-332X \\ Azov Maritime Institute of National Азовський морський інститут НУ \\ University "Odessa Maritime \\ Academy» \\ 19, Chornomorska Street, \\ Mariupol City, Ukraine, 87517 \\ «Одеська морська академія» \\ $\triangle$ вул. Чорноморська 19, \\ м. Маріуполь, Україна, 87517
}

Original manuscript received: March 17, 2021

Revised manuscript accepted: April 20, 2021

\section{ABSTRACT}

The modern process of teaching the professionals, who are able to solve their occupational problems, should provide not only the formation of professional competencies, but also the development of thinking, self-determination, skilled workers' readiness for independent action, ability to take responsibility for themselves and their actions. Currently, the most common language for international communication is English. English for Professional Purposes has a significant impact on the formation of a modern maritime transport specialist due to the expansion of international contacts in the maritime industry with foreign companies' representatives, the development of new foreign technologies. There is a need for competent professionals who speak a foreign language adequately as a means of solving industrial problems, taking into account the specifics of the intercultural communication. Therefore, the level of English language determines the success of the navigator operation, his career growth, ensuring the safety of navigation.

This article characterizes the features of teaching a foreign language in maritime institutions of higher education; the existing views on the content of the discipline "English for Professional Purposes" are analysed; the importance of teaching maritime English to ensure the safety of navigation is considered, the terms "Professionally Oriented English", "English for Academic Purposes" and "English for Occupational Purposes" are defined.

English for Professional Purposes refers to the language and related practices that people need for studying or work in a higher education system in English language. Thus, the purpose of the English for Professional Purposes course is to help such people to learn some linguistic and cultural practices related to learning or working in English. English for Academic Purposes is often considered a type of English for Specific Purposes along with English for Professional Purposes and English for Occupational Purposes, in which the education content clearly corresponds to the language, practice and study requirements of students.

Key words: professionally oriented English, English for educational / academic purposes, English for professional purposes, maritime safety, navigation, misunderstandings. 
Постановка проблеми. Аналіз нещасних випадків на морі дозволяє нам зробити висновок про те, що понад 80\% аварійних ситуацій виникає через так званий «людський фрактор». Існують численні публікації, де розглядаються причини випадків і супутні їм обставини, аналізуються зовнішні чинники, через які сталася аварійна ситуація; наводяться психологічна характеристика й аналіз стану моряків тощо. Але ми не можемо не зупинитися на ще одному факторі через який відбуваються зіткнення, посадка на мілину, затоплення судна, тощо, - це погане володіння англійською мовою.

Аналіз попередніх досліджень і публікацій. Аналіз понять «професійно орієнтована англійська мова, англійська мова для навчальних / академічних цілей» відображений у багатьох наукових дослідженнях Т. Dudley-Evans, T. Hutchinson, A. Waters, P. Strevens, Н. Widdowson, І. Попко, Є. Мусницька, Д. Гоулман, О. Кузнєцова, О. Санкова, А. Харбін, І. Шестопалова. Однак у їхніх роботах не розглядається спілкування іноземною мовою як вимога до підготовки фахівців морського транспорту. У міжнародних морських документах, зокрема в Конвенції про підготовку і дипломування моряків та несення вахти 78/95, наголошується на необхідності наявності у вахтових помічників капітана іншомовної професійної компетентності: «Достатнє знання англійської мови, яке дозволяє вахтовому помічнику користуватися картами та іншими морськими посібниками, розуміти метеорологічну інформацію і повідомлення щодо безпеки суден та їхньої експлуатації, а також уміння чітко висловлювати свої думки під час зв'язку з іншими суднами чи берегом, умінні розуміти і використовувати Стандартний морський словник IMKO» (STCW, 2020).

Метою статті $€$ проаналізувати поняття English for Specific Purposes (англійська мова для спеціальних цілей) та English for Academic Purposes (англійська мова для навчальних/академічних цілей) та зробити акцент на значенні морської англійської мови в забезпеченні безпеки в морській індустрії.

Результати та дискусії. Володіння англійською мовою $є$ однією 3 найважливіших вимог підготовки майбутніх фахівців морської галузі, зокрема судноводіїв. Іноді непорозуміння, низький рівень знання морської англійської мови можуть привести до фатальних наслідків, наприклад, до загибелі людей, екологічних катастроф, збитків на мільйони доларів тощо.

Володіння англійською мовою професійного спрямування входить у кваліфікаційні характеристики фахівців морських професій та $\epsilon$ професійно важливою якістю підготовки. Наявність іншомовної професійної компетентності у вахтового помічника капітана обумовлено Міжнародною конвенцією про підготовку і дипломування моряків та несення вахти (ПДМНВ 78/95) - International Convention on Standards of Training, Certification and Watchkeeping for Seafarers 78/95 (STCW) (STCW, 2020). 
Національні навчальні програми морських закладів вищої освіти включають компоненти «Англійська мова» та «Англійська мова за професійним спрямуванням». Державними освітніми стандартами вищої професійної освіти передбачається вивчення іноземної мови саме так називається дисципліна в навчальних програмах підготовки фахівців різних профілів. Але здобувачеві вищої освіти в немовних закладах вищої освіти необхідні знання не стільки іноземної (англійської) мови взагалі, скільки англійської мови для спеціальних цілей, або професійно орієнтованої англійської мови - English for Specific Purposes (ESP).

Термін ESP добре відомий більшості викладачів іноземних мов, проте ESP часто підміняється так званою англійською мовою для навчальних / академічних цілей - English for Academic Purposes (EAP).

У практику викладання іноземних мов давно ввійшло поняття ESP. Так, T. Hutchinson та A. Waters (Hutchinson T., Waters A., 1987) вважають, що ESP - це підхід, який не має на увазі наявності якоїсь окремої мови, дидактичних матеріалів або методик. На їхню думку, відповідь на питання, навіщо необхідно вивчати іноземну мову конкретному здобувачеві вищої освіти, лежить в основі ESP. Потреби визначаються причинами, за якими здобувач освіти вивчає англійську мову: для роботи або для продовження навчання після закінчення закладу вищої освіти. Вибір мови, що вивчається, залежить саме від зазначених причин.

P. Strevens (Strevens P., 1988) виділяє абсолютні та змінні характеристики ESP. До абсолютних він відносить: ESP відповідає певним потребам тих, хто вивчає мову; ESP за своїм змістом відноситься до конкретної дисципліни, роду занять або діяльності; ESP орієнтується на мову, що характерна такій діяльності в синтаксичному, лексичному, дискурсивної або семантичному планах, а також на аналіз власне дискурсу; ESP протистоїть англійській мові для загальновживаних цілей General English (GE). На його думку, змінними характеристиками є: ESP може обмежуватися лише тими навичками, які передбачаються для освоєння (наприклад: тільки читання або письмо); навчання може проходити поза якоїсь заздалегідь визначеної методики.

P. Robinson (Robinson P.,1991) дає визначення ESP, також ґрунтуючись на пріоритетності аналізу потреб, і виділяє основні критерії ESP та низку характеристик, що відносяться до ESP. Ключовий критерій - це цілеспрямованість, тобто курс ESP повинен бути розробленим на основі аналізу потреб, метою якого $є$ найбільш точне визначення того, чим здобувачеві вищої освіти доведеться займатися в англомовному середовищі. Характеристики ESP: курси ESP обмежуються тимчасовими межами, впродовж яких необхідно досягти поставлених цілей; навчання відбувається в однорідних групах з точки зору професійної діяльності з урахуванням тем, аспектів або спеціальностей, у яких майбутнім фахівцям доведеться функціонувати. 
T. Dudley-Evans i M. St John (Dudley-Evans T., St John M., 2003) вважають, що у визначенні ESP слід ураховувати той факт, що при навчанні ESP значною мірою (особливо там, де воно дуже зближується 3 конкретною професією або дисципліною) необхідно застосовувати методи навчання, які будуть відмінні від тих, що використовуються при викладанні загальновживаної англійської мови. У цьому випадку під методами навчання ними розуміється характер взаємодії між викладачем ESP та здобувачем вищої освіти. При вивченні більш загальних тем на заняттях з ESP ця взаємодія може бути наближена до занять з загальновживаної англійської мови.

При викладанні більш спеціалізованих тем викладач іноді стає таким собі консультантом з мовних питань, в той час як здобувачі освіти мають статус у профресійних питаннях. На їхню думку, все навчання ESP має неодмінно відображати методи навчання, що застосовуються в дисципліні або професії, на «службі» якої саме знаходиться ESP.

Усі наведені вище визначення дають нам змогу зробити висновок, що курс ESP розробляється з урахуванням конкретних потреб майбутнього фахівця і $є$ абсолютно необхідним для усвідомлення цілей, відповідно до яких здобувач освіти вивчає англійську мову. Крім того, ESP розрахована на здобувачів вищої освіти з хорошим знанням мови; в більшості випадків курси ESP допускають наявність базових знань системи мови, але, крім того, можуть застосовуватися й серед початківців вивчення іноземної мови.

Традиційно для немовних закладів вищої освіти в нашій державі навчальні плани більшості технічних дисциплін включають досить короткий курс іноземної мови тривалістю 3-4 семестри на I-II курсах. Як результат, виникає необхідність навчати професійно орієнтованої мови здобувачів освіти, які мають лише базові відомості про обрану ними спеціальність. При мінімальній кількості годин, що відводяться навчальною програмою на вивчення дисципліни, - завдання практично нездійсненне.

У цьому випадку мова, якої слід навчати студентів, - англійська мова для навчальних цілей (ЕАР). ЕАР відноситься до викладання англійської мови в навчальних цілях, коли в здобувача освіти формуються різні вміння та навички, необхідні при навчанні у вищому закладі освіти: вміння скласти конспект лекції, рефрерат, анотацію, прочитати статтю або текст, зробити доповідь або повідомлення на заздалегідь задану тему, підготувати презентацію тощо. На думку H. Widdowson (Widdowson H., 1983), в ЕAP необхідно застосовувати методи навчання, які б були спрямовані на вирішення проблем в освітньому процесі або пов'язаних з ним.

Але разом з тим існує низка професій, що вимагають досить високого рівня володіння англійською мовою для професійних цілей (EOP), наприклад, судноводіння. В цьому випадку ЕOP має на увазі цілком конкретні цілі професійної спрямованості в галузі судноводіння.

Для цього дослідження ми дотримуємося визначення морської англійської мови P. Trenkner (Trenkner P., 2000), який вважає, що 
морська англійська мова - це всі ті засоби англійської мови, які використовуються як інструмент забезпечення комунікації міжнародного морського співтовариства, забезпечують безпеку судноводіння та сприяють всебічному розвитку морської галузі.

На думку фахівців в галузі морської англійської мови (А. Glover, E. Johnson, D. Kalogjera, B. Pritchard, P. Strevens, P. Trenkner, F. Weeks), з лінгвістичної точки зору морська англійська мова це певний різновид професійно орієнтованої англійської мови. Ії̈ відмінність від інших різновидів ESP полягає в частотності вживання визначених лінгвістичних форм, а також специфічному відборі деяких (лексичних, граматичних чи прагматичних) характерних засобів загальновживаної англійської мови. Власне кажучи, не окрема мова, а лише її різновид, що була спеціально затверджена морським співтовариством і наполегливо рекомендована для використання фахівцями морської галузі для досягнення ефективної комунікації в повсякденному житті на борту судна, при спілкуванні між судами та з береговими станціями.

Морська англійська мова, на думку С. Cole, B. Pritchard, P. Trenkner (Cole C., Pritchard B. and Trenkner P., 2007), є свого роду комплекс реалізацій англійської мови, яка:

а) відноситься до певного морського оточення або фону (в процесі судноводіння, при вирішенні ситуацій небезпечного зближення суден, запитах про постановку судна на якір чи відшвартовку тощо) при проведенні вантажних операцій;

б) використовується в певному контексті або ситуаціях (на борту судна або в порту; на березі в доці тощо);

в) передбачає участь представників певних суднових або берегових мовних спільнот;

г) використовується в ситуаціях спілкування, пов'язаних з різними обставинами роботи в морі; коли на успішність комунікації впливають різні фактори (при отриманні або відправленні радіотелефонних повідомлень, усній взаємодії в рульовій рубці тощо);

д) використовується та формується за певних соціолінгвістичних обставин (специфічна взаємодія між тим, хто слухає та говорить, при забезпеченні радіотелефонних переговорів, які часто здійснюється в умовах стресу або навіть паніки).

При викладанні морської англійської мови необхідно враховувати її лінгвістичні характеристики, властиві морському дискурсу, тексту, комунікації. Головним чином, сюди відносяться типова або найбільш частотна технічна термінологія та певні граматичні конструкції.

Крім того, морська англійська мова здійснює лінгвістичний вплив на англомовні морські співтовариства, що відбувається в процесі постійного перекодування й лінгвістичних запозичень, де англійська мова виступає мовою-донором. Англійська мова $є$ важливим навчальним інструментом при отриманні знань ув галузі морської науки і техніки. Цей факт має велике значення при викладанні морської англійської мови. Виникає потреба в проведенні групового навчання, 
коли викладачі англійської мови та спеціальних дисциплін працюють разом (C. Cole, B. Pritchard, P. Trenkner).

I, нарешті, слід зазначити, що на морі, крім вербальних, використовуються також невербальні та семіотичні системи, мова знаків і паралінгвістичні елементи, як-то попереджувальні знаки й таблички на палубі, в машинному відділенні, інших приміщеннях; маркування буїв і берегових знаків, звукові сигнали тощо. Незалежно від того, в якій формі (усній або письмовій) вони застосовуються, це надійні засоби комунікації, що використовуються як на борту судна, так і між судами, судном і береговими об'єктами.

Англійська мова також є основним засобом спілкування учасників мовленнєвого процесу, які представляють багатомовну аудиторію, що складається з представників різних культур, як на судні, так і на березі. Можна стверджувати, що спілкування англійською мовою в портах, доках, на фарватерах, в протоках і міжнародних морських шляхах здійснюється між учасниками комунікації, які не $є$ носіями мови. Тобто людьми, для яких англійська мова є іноземною. Таким чином, морська англійська мова - це «лінгвафрранка» морського співтовариства.

3 метою забезпечення безпечного та успішного спілкування на морі міжнародним морським співтовариством робилися спроби впровадження норм ведення радіотелефонних переговорів на морі, створення певного стандартного словника термінів тощо. У 1973 році на 27-й сесії Комітету з морської безпеки Міжнародної морської організації (MMO) International Maritime Organization (IMO) було прийнято рішення про необхідність встановлення рівнів володіння англійською мовою та лексичного мінімуму, що необхідні для забезпечення безпеки мореплавства.

До 1977 року ММО розроблений та схвалений Стандартний морський навігаційний словник (Standard Marine Navigational Vocabulary), хоча він не був рекомендований для обов'язкового використання моряками. Згодом до першого варіанту словника були внесені доповнення та зміни.

Крім Стандартного морського навігаційного словника, у 1982-83 роках фрахівці в галузі морських комунікацій та прикладної лінгвістики розробили «SEASPEAK» - спеціальну англійську мову для забезпечення зв'язку між судновими та береговими станціями. Однак SEASPEAK - це мова, обмежена рамками ії застосування - ведення радіопереговорів на морі. SEASPEAK відрізняється лаконічністю, однозначністю, також особливим форматом повідомлень. При всій оптимальності цей варіант англійської мови має вкрай вузьку сфреру застосування, отже, обмежуватися лише його вивченням у рамках профресійно спрямованої англійської мови неприпустимо.

Різні нещасні випадки на морі, які мали велику кількість жертв або призвели до тяжких екологічних наслідків через недостатнє володіння екіпажем морською англійською мовою, сприяли активізації робіт над морською мовою. Наведемо приклад порівняно недавніх подій: пожежу на 
поромі «Scandinavian Star», що призвела до загибелі 158 осіб. Однією 3 причин, що вплинули на тяжкість, на думку експертної комісії, стало невідповідне володіння англійською мовою членами екіпажу. Низький рівень знань англійської мови, поряд з іншими фракторами, суттєво ускладнив евакуацію пасажирів і збільшив кількість жертв.

Аварійний розлив нафти 3 танкера «Sea Empress» у результаті посадки на мілину. Китайський буксир-рятувальник «De Yue» прибув до місця лиха через кілька годин, однак на суднініхто не володів морською англійською мовою. У найвідповідальніший момент проведення рятувальної операції, коли швидкість і професіоналізм рятувальників могли істотно знизити збитки, нанесені судну, екіпажу та довкіллю, виникла плутанина. Трагікомічність ситуації полягала ще й в тому, що єдиний, до кого вдалося звернутися за допомогою, виявився китайський кухар з ресторану в Milford Haven. Ця людина допомогла в переговорах між екіпажем буксира та представниками рятувально-координаційного центру й влади. Судно повторно сіло на мілину та в цьому випадку розлив нафтти збільшився з 2500 тон до 71800. Досить складно оцінити суму збитків через проблеми з взаєморозумінням учасників рятувальної операції. Проте можна з усією визначеністю стверджувати, що, якби проблема з непорозумінням не виникла, допомога буксира була б більш ефективною, не було б повторної посадки на мілину, отже, й не відбулося б повторного розливу нафрти.

Засідання підкомітету з безпеки мореплавства прийняло рішення про перегляд Стандартного морського навігаційного словника з метою його переробки та розширення. У редагуванні словника брали участь фахівці в галузі судноплавства, прикладної лінгвістики, різні компанії та організації (Асоціація морських лоцманів, Асоціація працівників маякових служб і засобів судноводіння, різні підкомітети ММО, тощо.). Новий варіант словника отримав назву Стандартні фррази для спілкування на mopi (Standard Marine Phrases for Communication at Sea - SMCP).

Це універсальний набір фраз, призначений для забезпечення безпеки мореплавства та захисту морського середовища, $\epsilon$ обов'язковим для застосування всіма учасниками комунікації. їх ціль спростити та уніфрікувати спілкування на морі. Використання фрраз для ведення обміну на морі стало одним з головних вимог і занесено до міжнародних конвенційних документів (ПДМНВ 78/95), що регулюють підготовку фахівців морського профрілю.

Однак, на нашу думку, існування стандартних фраз не звільняє від необхідності навчання всіх використовуваних на практиці форм спілкування, реальних, розмовних форм комунікації. Більш того, різноманітність видів мовленнєвої діяльності, що є характерною для роботи судноводія, а часом і непередбачуваність ситуацій спілкування, в яких може опинитись судноводій та судно, вимагають навчання майбутніх морських спеціалістів не лише стандартним фразам. Слід зауважити, що судноводій не може функціонувати тільки в умовах судна, його робота - складний комплекс різних видів діяльності як в 
морі, так і на березі. Знання загальновживаної англійської мови при цьому також $є$ необхідним.

Висновки. Підсумовуючи вищесказане, вважаємо, що дисципліна в курсі підготовки фахівця-судноводія незалежно від її формальної назви в навчальних планах («Англійська мова (за професійним спрямуванням)», «Морська англійська мова», «Ділова англійська мова в судноводінні»), $є$ морська англійська мова - Maritime English (ME). Це професійно орієнтована англійська мова для судноводіїв (ESP) або англійська мова для професійних цілей судноводіїв (ЕОР). Морська англійська мова використовується як інструмент комунікації міжнародного морського співтовариства, забезпечуючи безпеку судноводіння, та сприяє всебічному розвитку морської галузі.

Перспективи подальшого дослідження полягають в аналізі особливостей та специфіки організації освітнього процесу в морських закладах вищої освіти.

\section{References}

Cole C., Pritchard B. and Trenkner P. Maritime English Instruction - Ensuring Instructors' Competence. IBERICA Journal, 14, 2007.

Dudley-Evans T., St John M. Developments in ESP. Cambridge: Cambridge University Press, 2003.

Hutchinson T., Waters A. English for Specific Purposes. Cambridge: Cambridge University Press, 1987.

International Convention on Standards of Training, Certification and Watchkeeping for Seafarers (STCW Convention, as amended (IMO Sales No.IB938E).

Robinson P. ESP today: A Practitioner's Guide. Hemel Hempstead: Prentice Hall International, 1991.

Strevens P. ESP after Twenty Years: a Re-appraisal. In Tickoo M. (Ed.) ESP: State of the art. Singapore: SEAMEO Regional Language Centre, 1988.

Trenkner P. Maritime English. An attempt at an Imperfect Definition. Dalian: Dalian Maritime University, 2000.

Widdowson H. Learning Purpose and Language Use. Oxford: Oxford University Press, 1983.

\section{АНОТАЦІЯ}

Англійська мова за професійним спрямуванням має значний вплив на формування сучасного фрахівия морського транспорту. На сьогодні вона $\epsilon$ одним із найважливіших засобів профресійного спілкування фахівців морської галузі та є досить специфрічною. У статті характеризуються особливості викладання іноземної мови в морських закладах вищої освіти; аналізується зміст дисципліни "Англійська мова за професійним спрямуванням»; розелядається значення викладання цієї навчальної галузі з метою забезпечення безпеки мореплавства, дається визначення термінів «професійно орієнтована англійська мова» (ESP), «для навчальних/академічних иілей» (English for Academic Purposes) $і$ «для професійних цілей» (English for Occupational Purposes).

Ключові слова: профресійно орієнтована англійська мова, англійська мова для навчальних/академічних цілей, безпека в мореплавстві, судноводіння, непорозуміння. 